\title{
Organoleptic Test and Total Acid Level of Buffalo Milk and Goat Milk by Using Bamboo Ampel (Bambusa vulgaris) and Bamboo Gombong (Gigantochloa verticilata).
}

\author{
Muhammad Amrin Siregar, Nurzainah Ginting, R. Edhy Mirwandhono, Yunilas, \\ Tri Hesti Wahyuni
}

\author{
Animal Production Study Program, Faculty of Agriculture, Universitas Sumatera \\ Utara, Padang bulan Medan 20155 \\ muhammadamrinsiregar@gmail.com
}

\begin{abstract}
The purpose of this research is getting know the organoleptic test of buffalo milk and goat milk by using bamboo ampel (Bambusa vulgaris) and Bamboo Gombong (Gigantochloa verticilata). This research was done at Food Technology Laboratory of Agricultural Faculty of University of Sumatera Utara in May 2017 - June 2017. The design is used in this research is a complete randomized design of factorial pattern by using two factors, they are milk factor (S): (S1 / buffalo milk and S2 / Goat milk) and the second factor is bacteria (B): (B1 / without using bamboo, B2 / using bamboo Gombong, B3 / using bamboo ampel). Parameters analyzed were Color, Aroma, Flavor, Texture and Total Acid Level.

The results showed that the milk curd of buffalo milk and the milk curd of goat milk using bamboo ampel and bamboo gombong gave a not significant different effect $(\mathrm{P}<0.01)$ on the organoleptic value of color, smell, taste, texture and total acid level. Can be known milk milk buffalo and goat milk by using bamboo ampe and bamboo gombong more than curried milk milk and goat milk without using bamboo, for the total acid content is the same as the use of bamboo gombong without using bamboo.
\end{abstract}

\section{Introduction}

In general, buffalo milk is similar to cow's milk and other ruminants, which contain water, protein, fat, lactose, vitamins and minerals only with different propersi. Buffalo milk has a high fat and protein content compared to other dairy fats and milk proteins.

Sources of good and perfect food one of which is milk, because milk contains nutrients that are so important in growth. As human needs continue to increase the need for milk production continues to be improved. Curd is a traditional food of West Sumatra, especially in Minang Kabau area.

Curd processing is done traditionally with the basic ingredients of pure milk buffalo is put into bamboo tubes and bamboo is used is a type of bamboo ampel (Bambusa vulgaris). This bamboo has several types of microbes in the middle and can naturally ferment buffalo milk into curd for 2-3 days covered with banana leaves.

Some of the above reasons, the researchers are interested to conduct research on organoleptic test and total milk content of buffalo milk and goat milk using bamboo ampel (Bambusa vulgaris) and bamboo gombong (Gigantochloa Verticilata).

\section{Materials and methods}

21.Place and time of research

This research is in Food Technology Technology Laboratory Department of Food Science and Technology Faculty of Agriculture University of North Sumatera. The study was conducted from May 2017 to June 2017.

\subsection{Metodo Research}

The research method used was Factorial Randomized Complete Random (RAL) with 2 factors, ie factor 1 (milk with 2 levels) and factor 2 (bacteria with 3 levels) 6 treatment treatments and 3 replications. As for The linear method used by Yitnosumarto (1993) is:

$$
Y_{i j}=\mu+\alpha_{i}+\beta_{j}+(\alpha \beta)_{i j}+\varepsilon_{i j k}
$$


Yij: response or observation value from the $\mathrm{i}$-th treatment and $\mathrm{j}$-th repetition

$\mu$ : common middle value

ai: the influence of level susupada factor

to-i

$\beta \mathrm{j}$ : influence of Bacteria factor on

j-level

$(\alpha \beta)$ ij: the interaction of milk and bacteria on

level A to-i, level B ke-j

eijk: Experiment error for level i

milk, $\mathrm{j}$-level bacteria replicate

to-k

Preparation of Curd

Provide bamboo with diameter $\pm 4-5 \mathrm{~cm}$ and cut $\pm 15 \mathrm{~cm}$. Then buffalo milk is heated for 10 minutes at 80

${ }^{\circ} \mathrm{C}$ and then cooled before it is put into the bamboo and bamboo bamboo gombong. After buffalo milk cooled buffalo milk or goat milk put in bamboo as much as $200 \mathrm{ml}$ per bamboo. Then the bamboo is covered with a banana leaf that was first dilayukan then in fermentation for 2 days at room temperature.

\section{Parameter of Research}

\subsection{Organoleptic test}

Organoleptic properties are the properties of milk buffalo and goat's milk curd properties measured by means of the human senses, through differentiation and favorite tests. Flavor is a stimulus that arises from the curd after we know by means of the senses. Character Organoleptic properties observed include: Color, aroma, Texture Flavor

\subsection{Total Acid}

Total acid testing can be done by adding $10 \mathrm{ml}$ of water. Next add 3 drops of $1 \%$ phenolphthalene solution as indicator. Filling the burette with a $0.1 \mathrm{NaOH}$ solution, read the initial miniscuss and then until the milk color becomes reddish, and the color does not disappear within 30 seconds. Total acid content is known by the following formula

$$
\begin{aligned}
& \text { Acid content }=\frac{\mathrm{ml} \mathrm{NaOH} \mathrm{X} \mathrm{0.1} \mathrm{X} 100 \%}{\text { Sample weight (g) }} \\
& \text { (Usmiati et al., 2011). }
\end{aligned}
$$

\subsection{Implementation of research}

Prepared raw materials such as pure milk, bamboo, cooking stove, container (plate) and make a panelist study to be willing to be a tester on organoleptic tests.

Provided fresh water buffalo milk and pure goat milk then heated to $800 \mathrm{C}$ for 15 minutes then cooled for another 15 minutes refinement of casein wool (the formation of buttermilk) by inserting the milk in a bamboo tube and covered with banana leaf that is wounded after it is tempered with temperature room for two days

\subsection{Data analysis}

To know the level of panelist's preference on the curd was done by orgnoleptic test with 15 trained panelists. The calculation of data can be done by calculating all results of data provided by panelists with numbers then analyzed by factorial completely randomized design. If real results are obtained, or results are very real, proceed with the test (Duncan).

\section{Results and discussion}

\subsection{Color Organoleptic Value}

The average value of organoleptic color of buffalo milk curd and goat milk curd using bamboo ampe and bamboo gombong is S1B1 3,50 (kinda white), S1B2 3,90 (kinda white), S1B3 equal to 3,00 (kinda white), S2B1sesar 3, 83 (slightly white), S2B2 of 3.83 (slightly white) and S2B3 of 3.86 (slightly white). The influence of 
buffalo milk milk and goat milk using bamboo ampe and bamboo gombong on the organoleptic value of buffalo milk and goat milk curd can be seen in Table 5 .

\begin{tabular}{|c|c|c|c|c|c|}
\hline \multirow{2}{*}{$\begin{array}{l}\text { Perla } \\
\text { Kuan }\end{array}$} & \multicolumn{3}{|c|}{ Ulangan } & \multirow{2}{*}{ Total } & \multirow{2}{*}{ Rataan } \\
\hline & U1 & U2 & U3 & & \\
\hline S1B1 & 3,5 & 3,5 & 3,5 & 10,5 & $3,50^{\mathrm{C}}$ \\
\hline S1B2 & 3,8 & 4,0 & 4,0 & 11,8 & $3,90^{\mathrm{A}}$ \\
\hline S1B3 & 3,0 & 3,0 & 3,8 & 9,0 & $3,00^{\mathrm{D}}$ \\
\hline S2B1 & 3,8 & 3,8 & 3,9 & 11,5 & $3,83^{\mathrm{B}}$ \\
\hline $\mathrm{S} 2 \mathrm{~B} 2$ & 3,9 & 3,8 & 3,8 & 11,5 & $3,83^{\mathrm{B}}$ \\
\hline S2B3 & 3,8 & 3,9 & 3,9 & 11,6 & $3,86^{\mathrm{AB}}$ \\
\hline Total & & & & 65,9 & \\
\hline Rataan & & & & & 3,66 \\
\hline
\end{tabular}

Description: Different letter notation shows very different effect on note to the level of $1 \%$.

The result of analysis showed that the making of curcin using bamboo ampel and bamboo gombong to buffalo milk and goat milk gave no significant effect $(\mathrm{P}<0,01)$ on organoleptic value of buffalo milk and goat milk. Based on Table 5, it can be seen that the highest color organoleptic value obtained in the treatment of S1B2 (buffalo milk using bamboo gombong) is 3.90 criteria (kinda white) and not significantly different to the treatment of S2B3 (goat milk using bamboo ampel) with a value of 3,86 criteria (somewhat white

The color of buffalo milk milk and goat milk using bamboo ampel and bamboo gombong not much different from the real color (rather white). The milky white color is the result of the dispersion of the light reflection by the fat globula and the cloid particles of casein potassium phosphate, while the yellowish color is due to fat and karotein which is soluble in Saleh's milk (2004).

The color of buffalo and goat milk curd milk is influenced by BAL (Lactic Acid Bacteria) in bamboo kingpin and bamboo ampe so that the milk of goat and buffalo curd looks white, the color of the fine curd is yellowish white.

\subsection{Organoleptic Value of Aroma}

The organoleptic value of buffalo milk and goat milk curd with bamboo ampe and bamboo gombong varies from S1B1 to 3.20 (milks typical), S1B2, 3.86 (mildly typical milk), S1B3 of 4.00 (less typical of milk and smells of acid), S2B1 3,5 (mildly typical milk), S2B2 of 3.60 (typical milk aga) and S2B3 of 3.70 (mildly typical milk). Preparation of curd using bamboo ampel and bamboo gombong with organoleptic value can be presented in Table 6 .

\begin{tabular}{llllll}
\hline Perla & \multicolumn{3}{c}{ Ulangan } & \multirow{2}{*}{ Total } & \multirow{2}{*}{ Rataan } \\
Kuan & U1 & U2 & U3 & & $3,20^{\mathrm{D}}$ \\
\cline { 2 - 5 } S1B1 & 3,2 & 3,2 & 3,2 & 9,6 & $3,86^{\mathrm{C}}$ \\
S1B2 & 4,0 & 3,8 & 3,2 & 11,6 & $4,00^{\mathrm{A}}$ \\
S1B3 & 4,0 & 4,0 & 3,8 & 12,0 & $3,53^{\mathrm{C}}$ \\
S2B1 & 3,5 & 3,5 & 4,0 & 10,6 & $3,60^{\mathrm{C}}$ \\
S2B2 & 3,6 & 3,6 & 3,6 & 10,8 & $3,70^{\mathrm{B}}$ \\
S2B3 & 3,6 & 3,6 & 3,6 & 11,1 & 3,65 \\
\hline Total & & & & 65,7 & \\
Rataan & & & & & \\
\hline
\end{tabular}

Description: Different letter notation shows very different effect on note to the level of $1 \%$.

The result of the analysis showed that the making of buffalo milk curd and goat milk by using bamboo ampel and bamboo gombong gave no significant effect $(\mathrm{P}<0,01)$ on organoleptic value of odor

Preparation of curd using bamboo ampel and bamboo gombong gives the acidic aroma to the curd so as to reduce the typical smell in milk, because in the bamboo there are lactic acid bacteria that affect the aroma in typical milk, the higher the value of the acidic flavor of the curd, the typical aroma of milk is also increasingly reduced.

In addition, increasing secondary metabolites produced by yeasts such as acetate, suknisat, propionate, fumurat and pyruvate have a good influence on flavor (Choghe et al., 2004).

The curd made using freshly bamboo freshly cut has an effect on the aroma of the curd. Usmiat and Miskiyah (2011), stated that making curd using freshly cut fresh bamboo can produce a unique blend of fresh bamboo aroma and has a thick white color of curd. 


\subsection{Organoleptic Sense Value}

The organoleptic value of buffalo milk and goat milk curd by using bamboo ampel and bamboo gombong which varies are S1B1 equal to 3,43 (delicious), S1B2 equal to 3,13 (delicious), S1B3 equal to 3,00 (delicious), S2B1 equal to 3, 48 (delicious) S2B2 of 4.00 (better) and S2B3 of 3.63 (delicious). The influence of organoleptic value of buffalo milk and goat milk curd by using bamboo ampel and bamboo gombong can be presented in Table. 7

\begin{tabular}{|c|c|c|c|c|c|}
\hline \multirow{2}{*}{$\begin{array}{l}\text { Perla } \\
\text { kuan }\end{array}$} & \multicolumn{3}{|c|}{ Ulangan } & \multirow{2}{*}{ Total } & \multirow{2}{*}{ Rataan } \\
\hline & $\mathrm{U} 1$ & U2 & U3 & & \\
\hline S1B1 & 3,4 & 3,4 & 3,5 & 10,30 & $3,43^{\mathrm{B}}$ \\
\hline S1B2 & 3,0 & 4,2 & 4,2 & 9,40 & $3,13^{\mathrm{c}}$ \\
\hline S1B3 & 3,0 & 3,0 & 3,0 & 9,00 & $3,00^{\mathrm{D}}$ \\
\hline $\mathrm{S} 2 \mathrm{~B} 1$ & 3,5 & 3,4 & 3,5 & 11,46 & $3,48^{\mathrm{B}}$ \\
\hline S2B2 & 4,0 & 4,0 & 4,0 & 12,00 & $4,00^{\mathrm{A}}$ \\
\hline S2B3 & 3,6 & 3,6 & 3,7 & 10,90 & $3,86^{\mathrm{AB}}$ \\
\hline Total & & & & 65,9 & \\
\hline Rataan & & & & & 3,66 \\
\hline
\end{tabular}

Description: Different letter notation shows very different effect on note to the level of $1 \%$.

The result of analysis showed that the making of buffalo milk and goat milk curd using bamboo ampel and bamboo gombong gave no significant effect to $(\mathrm{P}<0,01)$ on organoleptic value of buffalo milk and goat milk with bamboo ampe and bamboo gombong. Based on Table 7, it can be seen that the organoleptic value of buffalo milk and goat milk curd using bamboo ampe and bamboo gombong the highest value obtained on the treatment of S2B2 (goat milk using bamboo gombong) of 4.00 with the criteria (better) and not significantly different to treatment of S2B3 (goat milk using bamboo ampel) with value equal to 3,63 criteria (delicious) and the lowest value found in treatment of S1B3 (buffalo milk using bamboo ampel) equal to 3,00 criteria (delicious).

Preparation of buffalo milk milk and goat milk by using bamboo ampel and bamboo gombong gives a better impression on the value of organoleptic taste. This is because the influence of the making of curd using fresh bamboo gives a distinctive flavor of bamboo and also the influence of bitter taste contained in bamboo. In addition, better taste is caused by banana leaves that are used as bamboo cover during the process of making milk buffalo milk curd and goat milk.

Sayuti (1992), states that there are three main things in the process of making curds namely bamboo preparation, milking and the process of curd. Bamboo used is a type of bamboo gombong (Gigantochioa verticilate) and bamboo ampel (Bambusa vulgaris). This type of bamboo is chosen because it tastes bitter so ants are not liked. Furthermore curd covered with taro leaves, banana leaves, plastic or without cover.

\section{4 rganoleptic Value of Texture}

The organoleptic value of buffalo and goat milk curd texture using bamboo ampe and bamboo gombong varies, ie, S1B1 of 3.06 (soft), S1B2 of 3.60 (soft), S1B3 of 3.66 (soft), S2B1 of 2, 60 (slightly soft), S2B2 of 3.60 (soft) and S2B3 of 3.53 (soft). The influence of buffalo and goat milk curds by using bamboo ampel and gombong on organoleptic value of texture can be presented in Table 8 .

\begin{tabular}{llllll}
\hline \multirow{2}{*}{$\begin{array}{l}\text { Perla } \\
\text { kuan }\end{array}$} & \multicolumn{3}{c}{ Ulangan } & \multirow{2}{*}{ Total } & Rataan \\
\cline { 2 - 4 } & U1 & U2 & U3 & & $3,06^{\mathrm{B}}$ \\
\hline S1B1 & 3,2 & 3,2 & 3,2 & 19,2 & $3,60^{\mathrm{c}}$ \\
S1B2 & 3,5 & 3,6 & 3,6 & 10,8 & $3,66^{\mathrm{D}}$ \\
S1B3 & 3,6 & 3,7 & 3,7 & 11,0 & $2,60^{\mathrm{B}}$ \\
S2B1 & 2,4 & 2,7 & 2,7 & 7,8 & $3,60^{\mathrm{A}}$ \\
S2B2 & 3,5 & 3,7 & 3,6 & 10,8 & $3,53^{\mathrm{AB}}$ \\
S2B3 & 3,5 & 3,6 & 3,6 & 10,6 & \\
\hline Total & & & & 60,2 & 3,34 \\
Rataan & & & & & \\
\hline
\end{tabular}

Description: Different letter notation shows very different effect on note to the level of $1 \%$ 
The results showed that the curd of milk buffalo milk and goat milk using bamboo ampel and bamboo gombong gave no effect

significantly different from organoleptic value of buffalo milk texture and goat's milk. Based on Table 8 , it can be seen that the highest texture organoleptic value obtained in the treatment of S1B3 is buffalo milk using bamboo ampe of 3.66 with the criteria (soft) and not significantly different to the S1B2 (buffalo milk using bamboo gombong and also S2B2 (goat milk using bamboo gombong) with the same value 3.60 criteria (soft)

The use of bamboo in the manufacture of curd using bamboo ampel or bamboo gombong affects better texture on curd. This is because lactic acid bacteria and some types of microorganisms that exist in bamboo one of them mold and yeast that contribute positively during the process of fermentation that spontaneously make milk can clot.

Chemical Test of Total Acid Content

The total value of the whey acid content without using bamboo with the total value of acid content in goat milk curd using bamboo gombong has the total value of acid content with the same value of 1.07. For the total value of the lowest acid content found in the treatment of S1B3 (buffalo milk using bamboo ampe) with a value of 0.35 . The total acid value of the study (Table 9) meets the SNI quality standards yougrht (SNI No. 01-2981-1992), ie 0.5$2 \%$.

The increase or decrease in the total acid value of the curd occurs due to the intensity and the number of changes in lactose to lactic acid due to BAL activity (Usmiati et al., 2011).

Recapitulation of Research Results

Based on the result of research recapitulation, it can be seen that the making of buffalo and goat's milk curd using bamboo ampe and bamboo gombong is preferred from buffalo milk curd and goat milk without using bamboo, for the total value of acid content with the same value on the use of bamboo gombong with without the use of bamboo.

\section{5.conclusion}

Preparation of buffalo milk milk and goat milk by using bamboo ampel and bamboo gombong can produce white curd color, thicker texture, excellent taste, aroma that is not typical of milk and not too sour.

\section{References}

[1] Coghe S,K., Benoot, F., Delvaux, B. \&Vanderhaegen. 2004. Ferulic acid release and 4-viny lguaiacol formationduring brewing and fermentation. J Agric Food Chem 52 (3): 602-608.

[2] Legowo, A. H. 2002. Buku Ajar Sifat Diponegoro. Semarang.

[3] Saleh , E. 2004. Teknologi Pengolahan Susu dan Hasil Ikutan Ternak. Fakultas Pertanian : Universitas Sumatera Utara. www.digilib.usu.ac.id (3)

[4] Sayuti, K. 1992. Studi Nilai Sosial dan Konsumsi Makanan Tradisional Dadih di Sumatera Barat, Studi Kasus di Kecamatan Lembag Gumantri, kabubaten solok, Provinsi Sumatera Barat. Fakultas Pertanian. Universitas Andalas.

[5] Usmiati, Sri dan Miskiyah. 2011. Sifat Fisikokimia Dadih susu Sapi: Pengaruh Suhu Penyimpanan dan Bahan Pengemas. Jurnal Penelitian dan Pengembangan Pascapanen Pertanian.

[6] Yitnosumarto.suntoyo, 1993. Percobaan Perancangan Analisa dan Interprestasi. PT. Gramedia PustakaUtamaJakarta. 
